\title{
The Indian Science Congress Association
}

\section{Lahore Meeting}

$\mathrm{T}$ HE twenty-sixth menting of the Indian Science Congress Association was held in Lahore in January, this being the third occasion upon which the Congress has met in the capital of the Punjab.

The president of the Association, Prof. J. C. Ghosh, professor of chemistry in the University of Dacca, devoted the first part of his address to a survey of the development in India of chemical research during the last decade. He showed that the appeal made by Prof. J. I. Simonsen in 1928 for a more intensive study of India's rich natural resources has met with a gratifying response, and, whilst deploring the lack of interest in inorganic chemistry, he was able to point to the valuable contributions made to physical chemistry. He directed particular attention to Prof. Bhatnagar's outstanding work in magneto-chemistry, to Prof. J. N. Mukherjee's elaborate investigations on the colloid chemical behaviour of soil constituents, and to the work of his own laboratory on the interplay of matter and radiation.

The second part of his address was an appeal for the formation in India of an All India Council of Scientific and Industrial Research. Research in agriculture has received generous support from public funds, but little or no attempt has been made to implement the recommendations of the Holland Industrial Commission. $\mathrm{He}$ suggested that there is little prospect of the schemes for industrial development, advocated at a recent conference of the Provincial Directors of Industry, meeting with success unless this development is supported by well-equipped and adequately staffod research organizations.

\section{The EARTh's MagnetisM AND The UPPER ATMOSPHERE}

The presidential address given by Dr. K. R. Ramanathan to the Section of Mathomatics and Physics was devoted to geomagnetism; it was an extremely interesting, well-balanced and up-to-date survey of this subject, which after many decades of relative neglect has again begun to attract the attention of physicists. Apart from the standing challenge to theoretical physicists which is offered by the problem of the existence of the main magnetic field of the earth (and also of its socular variation), the subject has come into new prominonce through its bearing on radio physics (the properties of the ionosphere) and on the entry of cosmic rays into the earth's atmosphere. Solar physicists are also concerned with the subject, because the timo-pattorn of geomagnetic disturbance, undoubtedly due to the sun, differs materially from that of the main changes hithorto observed on the sun's surface, and indicates that solar changes of much terrestrial significance are not yet proporly distinguished by solar observers.

Dr. Ramanathan's address was mainly devoted to the transient changes of the earth's field, which are associated with the sun and the ionosphere, but he also dealt briefly, at the outset, with the main field, in connexion with which he made some interesting quotations from the great memoir by Crauss on the spherical harmonic analysis of this field. In his survey of the transient variations, Dr. Ramanathan described the solar and lunar daily magnetic variations, magnetic storms, and--what is the most recently established type- the brief disturbances affecting only the day hemisphere, associated with radio fade-outs and solar eruptions. He rightly directed attention to the important contributions to geomagnetic science that have come from India, namely, the important work of Broun on the lunar daily magnetic variation, based on the data obtainod at the Trivandrum magnetic observatory maintained for many years by the Maharajah of Travancore, and the truly monumental discussion of the Bombay magnetic data, by Moos. In recent years now Indian contributions to ionospheric studies have come from Profs. Il. $\mathrm{N}$. Saha and S. K. Mitra and their students.

In his survey of geomagnetic problems, Dr. Ramanathan provided an admirable brief outline of the present state of knowledge in this field, which should be of value to physicists everywhere who desire an introduction to the subject.

\section{Analogy among Chemical Elements and Radicals}

The first part of the presidential address to the Section of Chemistry, by Prof. P. B. Sarkar, included an account of the volumes and magnetic properties of ions and the relation between these properties and colour with the electronic structures of the rare earth ions. The effect of deformability was considered in its relation to isomorphism, where the influence of ionic radii was fully explained.

In this part of the address special emphasis was laid on the modern explanation of cases of isomorphism which cannot easily be understood or explained on the older views. As an example, it is stated that the ionic radii of $\mathrm{S}^{6}+$ and $\mathrm{Be}^{2}+$ are both $0.34 \mathrm{~A}$. The only difference between the two ions is in their polarizing power. A series of isomorphous simple and double sulphates and corresponding fluoberyllates have been prepared by Ray, and in almost all cases the fluoberyllates resemble the corresponding sulphates in both physical and chemical proporties. The $\mathrm{X}$-ray spectrum of barium fluoberyllate is practically indistinguishable from that of barium sulphate.

Although pure alkali aluminium fluoberyllates corresponding with alums have not been prepared, mixed crystals of alums containing both sulphates and fluoberyllates have been obtained. Prof. Sarkar directed attention to the analogy between the monofluophosphate ion $\mathrm{PO}_{3} \mathrm{~F}^{\prime \prime}$ and the sulphate ion $\mathrm{SO}^{\prime \prime}$. Sevoral simple and double monofluophosphates as well as compounds of the alum type isomorphous with the corresponding sulphates liave been prepared in his laboratory. Anothor case of isomorphism supported by mixed crystal formation is afforlind by the formates and nitrites studied by Rây.

Prof. Sarkar concludes that three essential factors detormining chemical similarity are (i) equality of ionic charge or valency, (ii) similarity of structure, and (iii) approximate equality of ionic radii. of 
these the first is the most important and demands complete equality, whereas the other two permit of slight deviation within a narrow range.

\section{Conservation of India's Mineral Wealth}

Dr. S. K. Roy, in his presidential address to the Section of Geology, chose as his theme the conservation of India's mineral wealth. Considering the vast size of the country, mineral occurrences are few and far between, and for this reason alone they should be stringently conserved to meet the growing demands of industry and national defence. India possesses deposits of both coal and petroleum, and attention should be directed towards their conservation.

Owing to the number of serious accidents which have occurred during recent years, researches on safety in mines have taken precedence over fuel research. Hydraulic packing, known as sand-stowing, has been found by the Coal Mining Committee to be an efficient method of preventing practically all major disasters, and there is no reason, therefore, why this should not be put into practice by law and the energies of experts now turned towards fuel research. There is ample scope for this, particularly in the Jharia coalfield, where about 30 million gallons of tar are wasted annually in production of soft coke. of the 300 million gallons of petroleum consumed annually, only 76 millions are produced in India, and yet little is done to conserve the limited supply available.

Apart from coal and oil, there are a great many minerals which should be conserved. India is by far the largest producer of mica and could well command the world market were the industry efficiently organized. As things are, the mica deposits are for the most part exploited by unscrupulous small capitalists anxious only to fill their own pockets. Once they have recovered such mica as is easily available at the surface, they abandon the deposits. Thus in course of time valuable underground resources become overgrown and no one is aware of their existence. Another source of loss to the mineral wealth of India is the exceedingly low price at which minerals such as kyanite, magnesite, manganese, beryl, etc., are exported, simply because there is little domand for them within the country itself.

The history of India shows that years ago metals such as gold, silver and copper were available in large quantities. Diamonds also occur at three different geological horizons, and until the middle of the last century India supplied 98 per cent of the world's output. At the present time, however, diamond mining is extinct.

India cannot afford to ignore this wealth, which with the help of properly trained geologists, mining engineers and chemists, backed by local government departments, could be exploited to the advantage of the nation as a whole.

\section{The Geographical Personality of India}

The presidential address by Mr. N. Subrahmanyam to the Section of Geography and Geodesy covered widely, if superficially, almost every aspect of the life of India in an attempt to assess the present characteristics and the direction of change of Indian civilization to-day.

A review of physical factors, including climate and its effect on production, was comprised under the heading of static geography. Then followed under the heading of dynamic geography an account of the more modern influences that are permeating India and an estimate of their effect. India has long been awakening into modernity through impact with Europe, and particularly through British permeation. Her isolation has gone: new forces permeate cities and towns and through the motor-car and radio are reaching the villages, where eighty per cent of the inhabitants dwell. Self-sufficiency is rudely shaken : even caste is adapting itself to new conditions. The old conditions and obstacles to progress such as pressure on the land, recurrent famines and appalling poverty are no longer accepted; their courses are recognized to be removable.

In short, man in India has fallen behind, but now he is catching up and bids fair to take full advantage of his opportunities. A new composite civilization should emerge as a synthesis of Eastern and Western cultures. From the medieval India there is emerging, though naturally not without discord in places, a modern India.

\section{INDIAN FOREST MYCOLOGY}

Dr. K. D. Bagchee's presidential address to the Section of Botany dealt with Indian forest mycology with special reference to forest patholozy. It was in the early years of this century that Dr. E. J. Butler, at the time mycologist to the Agricultural Research Institute at Pusa inaugurated by Lord Curzon when Viceroy of India, wrote a papar or two on Indian forest fungi published in the Indian Forester. The subject, then almost a sealed book, has remained so until within the last few years. Dr. Bagchee's address shows that considerable progress is being made in a fascinating branch of forest studies, and one which will become of increasing importance in the years to come.

Dr. Bagchee stated that most of the forest diseases of India, including heart-rots, are indigenous. They seldom become epidemic, the organisms causing them being more or less in a biological balance with their hosts. When this balance is disturbed by unusual weather conditions or other factors, an indigenous disease temporarily becomes epidemic; when the disturbance ends, the disease resumes its former status, effecting cumulative damage through slow and constant action. But parasites coming into a new region often find some species particularly susceptible to their attack, because of the lack of any established balance between the parasite and the host, and thus an epidemic breaks out.

It may be pointed out that the balance mentioned above under which the primeval forest has maintained itself through the ages may be, and often is, interfered with by good forest management, the sylviculturist endeavouring to eliminate Nature's exuberant abundance in the production of material of little economic use and to increase the volume of the crop per unit of area whilst keeping it clear of dead and dying material. Whilst on one hand this should reduce the danger from insect or fungus pests, in epidemics the reverse may be the case. In plantations of one species, especially exotics, the forester has already realized the position.

Dr. Bagchee divided his subject into six main heads : (1) Coniferous rusts affecting conifers in the mountains; (2) root-and-stem-rotting fungi killing conifers in the mountains and hardwoods in the plains; (3) canker pathogens infesting native and 
some introduced hardwood species; (4) nursery diseases; (5) timber diseases-timber-rotting fungi ; (6) ecology and habits of the forest fungi of the forest floor or on the woody undergrowth or sub-aerial parts of the trees.

Dr. Bagchee discussed in some detail the diseases which he has studied, and dealt with certain possibilities of control measures. The address is a valuable contribution to the available knowledge on this subject.

\section{Batrachians -AND THEIR ENVIRONMENT}

The president of the Section of Zoology, Prof. C. R. Narayan Rao, directed attention in his address to changes induced in closely related frogs and toads by different influences of environment. The observations are of special interest because they are due to the author's own studies in an area of highly diverse physiographical conditions, and because they illustrate the possibilities that lie in ecological work of this kind. To select one or two of his points. We are accustomed to think of batrachians as limited to regions of great humidity, but some live continuously in "conditions of extreme dryness". These show distinctive adaptations : some inhabit deep burrows except during a short humid period ; in Uperodon the skin is developed to absorb and retain water, which may thus be available during drought. Aquatic batrachians have large kidneys; those attuned to dry conditions possess relatively small kidneys, a correspondingly large bladder and a surprisingly small amount of excretory products in the urine. Lastly, the aquatic forms reduce the exposed area of moist skin by resting flat upon the ground, whereas the others sit with a half-perpendicular pose.

Another striking correlation, suggested tentatively by Prof. Narayan Rao, is that between the presence or absence of the tympanum and the temperature of the air or water in which the batrachians live, for he finds that higher temperature leads to conspicuous development of the tympanum, lower temperature to its reduction or absence. Temperature seems also to rule the shape of the body, cold temperatures inducing rather globular forms with reduction of surface area; whereas high temperatures are associated with extensive surfaces, and with the habit of æstivation, which sets in at $105^{\circ} \mathrm{F}$.

Frogs typical of dense areas of jungle have elongated bodies and shortened hind limbs. Species represented both in forest and on high ground lay fewer eggs in hill streams and pools and, correlated with the smaller ovary, the fat-body also undergoes reduction. The studies made by Prof. Narayan Rao in South India offer many suggestions which workers in other parts of the world will be anxious to test upon their own amphibian population.

\section{Tribal Culture Contacts and Acculturation}

In India there are nearly thirty million primitive peoples, among whom tribal society in many areas is experiencing depopulation through changes in economic and social life. In certain groups, however, which have not lost their vitality and interest in life, cultural contacts bring about the selective adoption of alien traits, a cultural symbiosis or acculturation. This topic formed the subject of Dr. D. N. Majumdar's presidential address to the Section of Anthropology.

Nowhere in India is this cultural symbiosis or acculturation more patent than in Bastar, an important feudatory State of the Central Provinces. Here the native population is Gond. Foreigners and immigrants, claiming Kshatriya origin, are believed to have mixed freely with the native population. Two groups, having social precedence, claim Kshatriya origin; the remaining groups are regarded as of indigenous origin, probably with good reason. The linguistic and ethnic frontiers in Bastar are very uncertain; and it has for long been a melting-pot of races and groups. The infiltration into an aboriginal area of caste peoples, who dominate the native population, has resulted in an interdependence of the two groups. The Kabadi custom is an example of this interdependence and co-operation. According to this custom, when a member of one of the inferior groups is in urgent need of money, for example, for the payment of a fine, or to meet the expense of a ceremonial wedding, he will borrow from the master for whom he works, repaying by agricultural service. Formerly, when tribal organization was strong, if such a sum of money was required, it was raised by group effort. Now that tribal and group solidarity is dissipated, the economic helplessness of the inferior groups is exploited by the caste people, the loans often entailing lifelong servitude, which may pass to his heir, if a man dies while still in debt.

Nevertheless, in some areas economic interdependence has led to a healthy reciprocity in cultural life, as, for example, in the Dusserah religious festival, which has brought together the various cultural groups of Bastar as participants in a great cultural heritage. Further, many indigenous institutions survive to serve a useful purpose. Such, for example, is the dormitory institution, where unmarried youths and girls collect to dance and sing together at night. Originally, under tribal organization, this institution was intended to enable the warriors to lie in readiness to protect the women and property of the group from raids. It now serves as an educational institution, in which the young people learn the group standard of social life, discipline, the economic pursuits characteristic of the group, social and ceremonial duties relating to sex and associated matters. Thus the dormitory now fulfils an important role in the tribal life of the community.

\section{Insects and Their Role in Indian Agriculture}

Under this title Dr. T. V. Ramalkrishna Ayyar contributed an interesting presidential address to the Section of Agriculture. The substance of his discourse was a general survey of insects in relation to man and, in particular, in connexion with problems of Indian agriculture.

After discussing estimates of losses due to insect depredations in the United States, Dr. Ayyar compare similar losses in India. In so far as rice, wheat, cotton, sugarcane and oil-seed are concerned, he computes the annual losses of these crops, alone, at more than 200 million rupees. While the insect pest problems of the different areas of India differ considerably in geographical, climatic and other conditions, and according to the crops grown in each region, there are a few species of so wide a range as to affect India as a whole. Of these latter, locusts are of primary importance, and especially noteworthy was the large-scale infestation of the desert locust (Schistocerca gregaria) during 1926-31.

After reviewing various artificial methods of insect 
control, the subject of natural or biological control was then considered. In South India, biological control has so far been tried on an organized scale against two species of insect pests. One, the fluted scale (Icerya), which was introduced into the Nilgiris about 1927-28, has been considerably checked but not completely exterminated by the beetle Novius cardinalis. The other pest, the coco-nut caterpillar (Nephantis serinopa), is indigenous and has a complex association of various insects living in relation to it. A bionomical study of this association has been attempted, and some of the parasites have been found occasionally to exercise appreciable control over this caterpillar. In so far as pest plants are concerned, the cochineal (Dactylopius) has brought about a remarkable and spectacular result in the eradication of prickly pear.

In dealing with the organization of entomological work, Dr. Ayyar rightly stressed the importance of taxonomy and aptly remarked that discrimination between species is the starting-point of the majority of Indian biological problems. Other important aspects emphasized by him are the need for studies of ecology and of bioclimatics. He remarked that while pure science is often immensely practical and applied science is often very pure, between the two there is really no dividing line, both being necessary for the intellectual and material needs of man. In conclusion, he pleaded for the giving of greater encouragement in scientific institutions and universities to applied science, which is necessary to meet the many material needs of India.

\section{Physiological Research IN INDIA}

In his presidential address to the Section of Physiology, Prof. N. M. Basu made a plea for the establishment of physiological teaching and research in India, by the provision of better facilities for the holders of teaching posts, and the modification of existing degree courses to encourage the develop. ment of the student along the right lines. In spite of the many obstacles, much fruitful work has been carried out in India in recent times. The normal blood picture of the Indian has been established in many districts, and an extension of such work to other areas would be of the greatest value to the practitioner of medicine, as would an extension of the work on the standards of vital capacity and their relation to surface area and height.

Much time has been devoted to nutritional surveys and the investigation of the diets of various areas, and of the effect of supplementing those diets which were found to be defieient. Dietary surveys made in South Indian villages showed that not only are deficiency diseases common, but also the actual calorie intake is lower than the minimum. Addition of very small amounts of milk to such diets is very beneficial, chiefly through the calcium content of the supplement. The diet of middle-class Bengalee families has been found to be deficient in animal fat, animal protein and in calcium.

A considerable amount of work has been devoted to analyses of the composition of various foodstuffs, and to the determination of the biological values of the proteins of common Indian foods. Rice has a high biological value, and, together with pulses, forms a valuable addition to a diet. The vitamins have, naturally, attracted many workers. Vitamin C has been found to exist in large quantities in such native fruits as lichis, mango and guava, and the importance of this vitamin in aiding resistance to infection has been established. The occurrence and stability of carotene and vitamin $\mathrm{A}$ in indigenous plants has received attention, and observations of interest have been made on the effect of diet on the absorption of this vitamin from the alimentary tract. An inquiry into the requirements and saturation of various groups in vitamins $C$ and $B_{1}$ is now in progress, and promises to yield interesting results.

The preponderance of nutritional research is due to the fact that ample funds are available for it. If they were as well supported, other branches of physiology would advance as rapidly, and the subject would be able to take its full role in the development of biological science and medicine in India.

\section{Dynamic Structure of Human Personality}

In his presidential address to the Section of Psychology, H. P. Maiti pointed out that personality in its practical aspects meets us to-day wherever we have to deal with human nature, whether in hospitals, in clinics, in schools and colleges, or in industrial organizations.

There has always been a popular interest in personality, but until recently scientific psychology avoided it, probably because of its complexity. The work of the psychiatrists towards the end of the last century familiarized us with some of the problems of the abnormal personality, and Janet distinguished two main types of personality structure, namely, the 'psychasthenic' and the 'hysteric'. For psychiatric practice this work was fruitful, but it threw little light on the mechanism of personality integration. Nor in spite of the enormous amount of work devoted to their study have personality tests proved of reliable validity, probably because, if personality is a functional whole with interacting parts of which some are dominant over others, then no test or description can be adequate unless it can show the role of each part in the work of the whole. We need a dynamic theory of personality.

The most likely fields of study are $(a)$ the clinical and psycho-analytic fields, where variations of function through pathological deviations can be observed, and $(b)$ through observation of the normal changes attendant upon development.

The recent modification of the Freudian theory of the neuroses throws some light on a number of difficulties. The distinction of the Id, Ego, and Superego, roughly equivalent to the more popular distinction between passion, reason and conscience, shows the effect of the social influences of the early years on the rest of the personality. Genetically, the three are continuous one with the other, and can only be considered separate for functional purposes. The Id is undifferentiated instinct not yet organized under the unity of the Ego; the Ego gradually develops as the Id comes into contact with reality, and the Super-ego grows later out of the developing qualities of the Ego, thus helping the Ego to keep the Id in check.

These factors in their mutual interaction constitute the fundamental scheme of personality in an individual, and form a continuously active system, each part being in dynamic interaction with the other two. In the healthy mind the three structures harmonize, and retain their plasticity throughout life. 